\title{
Enhancing Ion Transfer in Overlimiting Electrodialysis of Dilute Solutions by Modifying the Surface of Heterogeneous Ion-Exchange Membranes
}

\author{
Natalia Pismenskaya, Nadezhda Melnik, Ekaterina Nevakshenova, \\ Kseniya Nebavskaya, and Victor Nikonenko
}

Membrane Institute, Kuban State University, Krasnodar 350040, Russia

Correspondence should be addressed to Victor Nikonenko, v_nikonenko@mail.ru

Received 30 March 2012; Accepted 24 May 2012

Academic Editor: Tongwen Xu

Copyright (C) 2012 Natalia Pismenskaya et al. This is an open access article distributed under the Creative Commons Attribution License, which permits unrestricted use, distribution, and reproduction in any medium, provided the original work is properly cited.

\begin{abstract}
The desalination of dilute $\mathrm{NaCl}$ solutions with heterogeneous Russian commercial and modified ion-exchange membranes was studied in a laboratory cell imitating desalination channels of large-scale electrodialysers. The modification was made by casting a thin film of a Nafion-type material on the surface of cation-exchange membrane, and by processing with a strong polyelectrolyte the surface of anion-exchange membrane. It was shown that the modifications resulted in an increase of mass transfer coefficient and in a decrease in water splitting rate, both by up to 2 times. The effect of mass transfer growth is explained by higher surface hydrophobicity of the modified membrane that enhances electroconvection. The decrease in water splitting rate in the case of cation-exchange membrane is due to homogenization of its surface layer. In the case of anion-exchange membrane the effect is due to grafting of quaternary ammonium bases onto the original membrane surface layer. The suppression of water splitting favors development of electroconvection. In turn, intensive electroconvection contributes to deliver salt ions to membrane surface and thus reduces water splitting.
\end{abstract}

\section{Introduction}

The applications of electrodialysis (ED) for water recovery in hybrid systems with $\mathrm{RO}[1]$ and in near zero liquid discharge (ZLD) systems [2], for ultrapure water production [3,4], and for salt production from sea water [5] are some examples of successful use of this process, characterized by high economic and ecological effectiveness [6]. Desalination/deionization of dilute solutions is one of the largest ED applications [6, 7]. However, the process rate in this case is limited by the delivery of electrolyte from bulk solution to the membrane interface. This delivery occurs mainly as electrolyte diffusion while the contribution of forced convection is vanishing when approaching the interface [8-10]. The usage of intensive current modes might be of practical interest, since it can significantly raise the ED process rate $[6,10]$.

The latest researches [10-12] show that one of the most promising ways of reducing diffusion limitations and enhancing the ED rate is the stimulation of current-induced convection, namely electroconvection. Electroconvection occurs as volume transport under the effect of an electric field imposed through the charged solution, in particular, through the electrical double layer (EDL). In the case where the space charge region (SCR) remains quasiequilibrium, electroconvection occurs as classical electroosmotic flow, named electroosmosis of the first kind [13-15]. When the applied current density is high enough, the SCR becomes nonequilibrium, it extends far beyond the quasiequilibrium EDL. Electroconvection caused by the action of the applied electric field upon the extended nonequilibrium SCR induced by the same electric field, is known as electroosmosis of the second kind [13-15]. Electroconvection produces microvortices, which actively mix the solution and may partially destroy diffusion boundary layer (DBL) in desalination channel at membrane surface $[11,15]$. Since the EDL thickness increases with decreasing electrolyte solution 
TABLE 1: Some characteristics of commercial MK-40, MA-40, and surface-modified MK-40/Nf and MA-40M membranes.

\begin{tabular}{|c|c|c|c|c|}
\hline \multirow{2}{*}{ Membranes } & \multicolumn{2}{|c|}{ Cation exchange } & \multicolumn{2}{|c|}{ Anion exchange } \\
\hline & MK-40 & $\mathrm{MK}-40 / \mathrm{Nf}$ & MA-40 & MA-40M \\
\hline Ion exchange groups, bulk & $-\mathrm{SO}_{3}{ }^{-}$ & $-\mathrm{SO}_{3}{ }^{-}$ & $=\mathrm{NH}, \equiv \mathrm{N}$ & $=\mathrm{NH}, \equiv \mathrm{N}$ \\
\hline Idem, surface & $-\mathrm{SO}_{3}{ }^{-}$ & $-\mathrm{SO}_{3}{ }^{-}$ & $=\mathrm{NH}, \equiv \mathrm{N}$ & $-\mathrm{N}^{+}(\mathrm{R})_{3}$ \\
\hline Thickness, $\mu \mathrm{m}$ & $480 \pm 10$ & $500 \pm 10$ & $470 \pm 20$ & $470 \pm 20$ \\
\hline Ion exchange capacity ${ }^{1}, \mathrm{mM} \mathrm{cm}^{-3}$ wet & $1.7 \pm 0.1$ & $1.7 \pm 0.1$ & $3.2 \pm 0.08$ & $3.2 \pm 0.08$ \\
\hline Surface fraction of ion exchange material ${ }^{2}, \%$ & $22 \pm 3$ & 100 & $19 \pm 4$ & $19 \pm 4$ \\
\hline Contact angle ${ }^{3}$, degrees & $55 \pm 3$ & $64 \pm 3$ & $50 \pm 2$ & $47 \pm 2$ \\
\hline Specific electrical conductivity in $0.5 \mathrm{M} \mathrm{NaCl}$ solution ${ }^{4}, \mathrm{mS} \mathrm{cm}^{-1}$ & $7.7 \pm 0.3$ & $8.3 \pm 0.3$ & $7.5 \pm 0.3$ & $5.5 \pm 0.3$ \\
\hline Diffusion permeability ${ }^{5}, 10^{-8} \mathrm{~cm}^{2} \mathrm{~s}^{-1}$ & $6.7 \pm 0.4$ & $6.6 \pm 0.4$ & $7.0 \pm 0.4$ & $6.7 \pm 0.4$ \\
\hline
\end{tabular}

${ }^{1}$ Ion exchange capacity was determined for wet membranes in the sodium form (cation exchange membranes) or in the chloride form (anion exchange membranes).

${ }^{2}$ Surface fraction of ion exchange material was determined for a wet membrane using SEM images by the method described in [21].

${ }^{3}$ Contact angle on the surface of wet membrane was found $20 \mathrm{~s}$ after placing a test drop, according to the method described in [18].

${ }^{4}$ Specific electrical conductivity of membrane in $0.5 \mathrm{M} \mathrm{NaCl}$ solution was determined by a difference method using a clip cell [28].

${ }^{5}$ Diffusion permeability of membranes was determined in $\mathrm{H}_{2} \mathrm{O} / \mathrm{IEM} / 0.5 \mathrm{M} \mathrm{NaCl}$ system using the cell described in [29]; the modified side of MK-40/Nf membrane was facing the $\mathrm{NaCl}$ solution; the left- and right-hand sides of $\mathrm{MK}-40, \mathrm{MA}-40$, and MA-40M membranes are symmetrical.

concentration, the rate of electroconvection should grow with diluting solution. This feature is especially important because it allows ED rate to be increased when treating diluted solutions $[10,15,16]$. Note that the extended SCR may be also used as a barrier for separating coions from counterions in a microchannel ED device [17].

In experiments using small-scale laboratory cells described in earlier publications $[10,18,19]$, we have shown that ion-exchange membrane surface modification can significantly enhance the ED rate in the range of $10^{-4}$ to $10^{-2} \mathrm{M}$ electrolyte solutions. Hydrophobization of cation-exchange membrane surface can stimulate the development of electroconvection due to change of the no-slip hydrodynamic boundary condition to the slip one $[10,18,20]$. In case of anion-exchange membranes, the treatment of surface by a strong polyelectrolyte containing quaternary ammonium bases leads to a decrease in the water splitting rate at the depleted membrane interface under intensive current densities. The effect is due to the substitution of secondary and tertiary amine groups, characterized by high catalytic activity in respect to water splitting reaction, by quaternary ammonium groups of low catalytic activity $[10,21,22]$.

In this paper we will study the behavior of modified ionexchange membranes in conditions close to those applied in large-scale electrodialysers. It will be shown that appropriate modification of heterogeneous membrane surface allows significant enhance of salt-ion transfer in real ED desalination processes.

\section{Ion-Exchange Membranes and Their Characteristics}

Heterogeneous cation-exchange MK-40 and anion-exchange MA-40 membranes (Shchekinoazot, Russia) are produced using a hot pressing method from polyethylene (as an inert binder) and ion-exchange resin powders, KU-2 and EDE$10 \mathrm{P}$, respectively. KU-2 is a sulfonated styrene-divinylbenzene copolymer; EDE-10P is produced by polycondensation of polyethylenepolyamines and epichlorohydrin. SEM images of surface and cross sections of a dry MK-40 membrane are shown in Figures 1(a), 1(b), 1(c), and 1(d). SEM images of MA-40 membranes look similarly. As it can be seen in Figures 1(b), 1(c), and 1(d), the diameter of ion-exchange resin particles is 10 to $30 \mu \mathrm{m}$.

Some characteristics of these ion-exchange membranes (IEMs) are represented in Table 1.

The membrane bulk contains from 35\% (MK-40) to $45 \%$ (MA-40) of polyethylene [23]. However, the surfaces of wet MK-40 and MA- 40 membranes are covered with polyethylene by about $80 \%$ (Table 1). The higher content of the binder in the near-surface layer is explained by the fact that at elevated temperatures used during the hot pressing, polyethylene is more fluent than the ion-exchange resin material.

Effective contact angle found experimentally for heterogeneous membranes under study is an average between its local values corresponding to the polyethylene and to the resin particles. The surface of MA-40 membrane is more hydrophilic, apparently due to higher exchange capacity of the resin in this membrane (Table 1).

The MK-40 membrane has sulfonic ion-exchange groups, which have low catalytic activity with respect to water splitting reaction $[24,25]$. The MA-40 membrane contains mostly secondary and tertiary amines as ionexchange groups, which are effective catalysts of this reaction $[24,25]$. Thereby the MA- 40 membrane is characterized by a high rate of $\mathrm{H}^{+} / \mathrm{OH}^{-}$ions generation at its depleted surface in intensive current modes [21]. In order to reduce water splitting, it is possible to replace secondary and tertiary amines on MA-40 surface with quaternary ones which are characterized by low catalytic activity. For this purpose, a commercial MA-40 membrane was modified by a copolymer of dimethyldiallylammonium chloride $[21,26]$.

The surface of MK-40/Nf membrane is completely covered with a thin $(20 \mu \mathrm{m})$ homogeneous film (Nf) with the same functional groups as that of the MK-40 membrane (Figures 1(e) and 1(f), Table 1). The film is formed by casting 


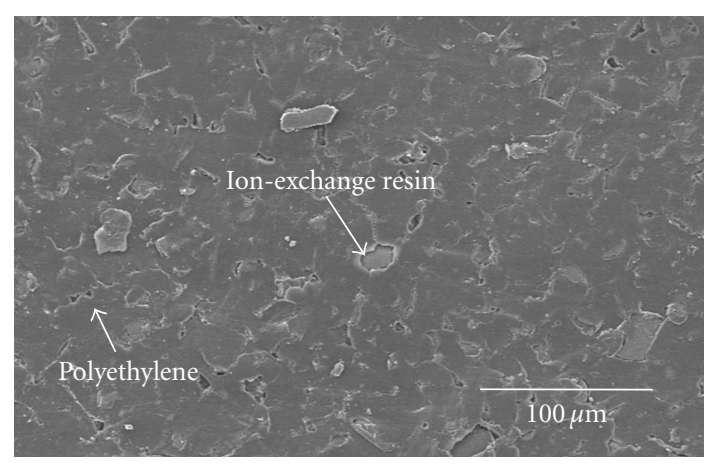

(a)

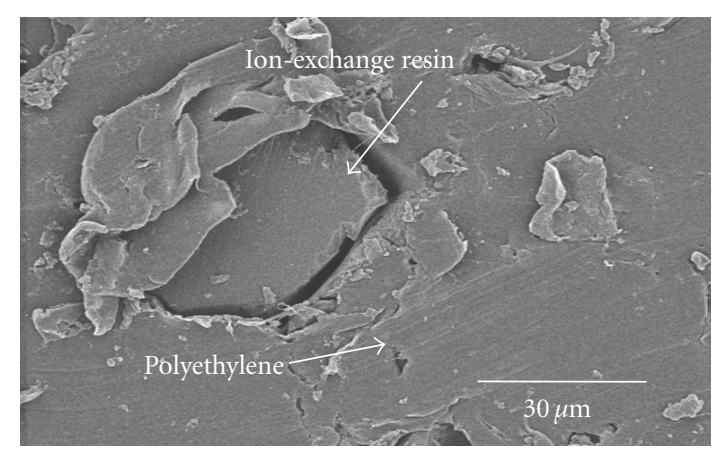

(c)

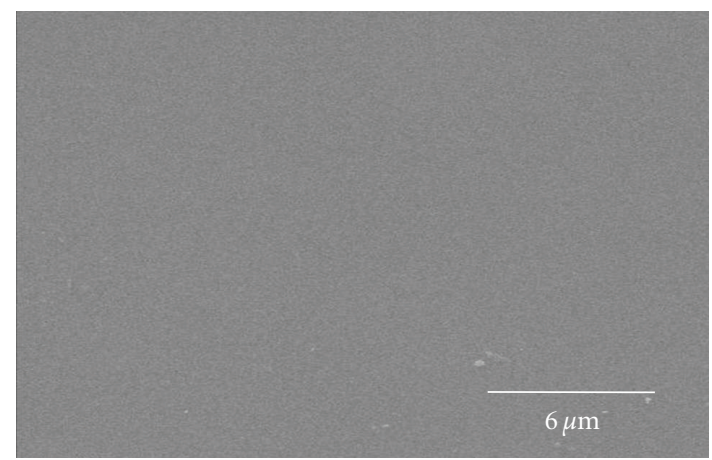

(e)

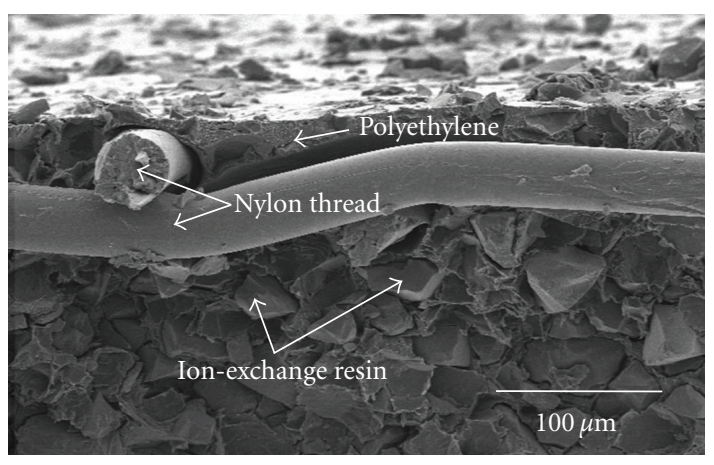

(b)

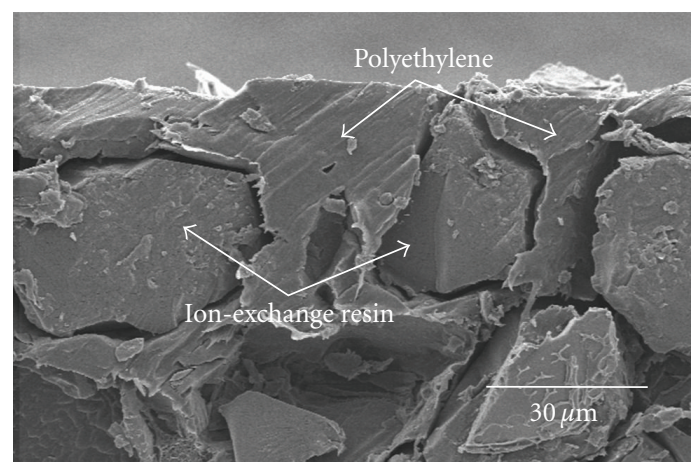

(d)

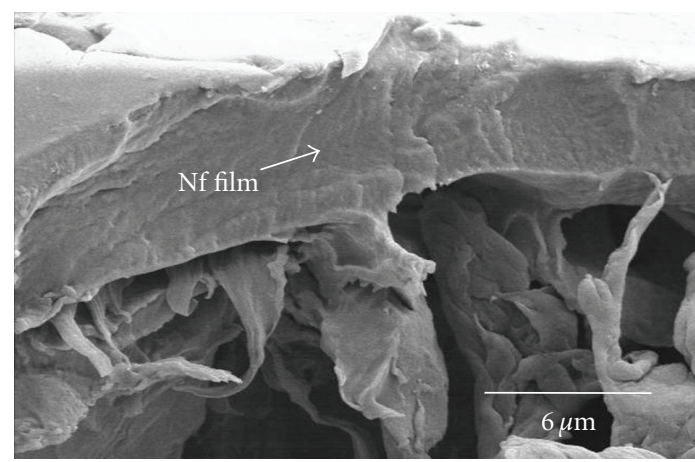

(f)

Figure 1: SEM images of the surface ( $a, c$, and e), the cross sections (b, d, and f) of a MK-40 (a, b, c, and d), and a MK-40/Nf (e, f) ionexchange membranes.

a 7\% MF-4SK solution in isopropyl alcohol (Plastpolymer, Russia) on the MK-40 membrane as substrate. MF-4SK is a sulfonated tetrafluorethylene and perfluorovinyl (alcohol) ether copolymer. The structure and properties of MF-4SK material are close to those of Nafion (DuPont Co.); they are thoroughly studied by Berezina et al. [27, 28]. As a result of casting perfluorinated film, the contact angle on MK$40 / \mathrm{Nf}$ membrane is increased (Table 1), and the membrane surface becomes homogeneous (Figure 1(e)). However, this modification does not lead to significant changes in electrical conductivity and diffusion permeability of modified MK$40 / \mathrm{Nf}$ membrane compared to the commercial MK-40 (Table 1).

\section{Method of Mass-Transfer Characteristics Measurements}

The principal scheme of experimental setup for mass-transfer characteristics measurements is shown in Figure 2.

The membranes forming desalination (DC), concentration (CC), and electrode (EC) compartments are separated from one another by an inert net spacer (S) of extrusion type with rhombic cells, situated at $45^{\circ}$ to ingoing stream. The step of the spacer cell is $5 \mathrm{~mm}$, the thickness is $1.0 \mathrm{~mm}$, and the porosity is 0.91 .

The membranes under study are designated with an asterisk $\left(\mathrm{MK}^{*}-40, \mathrm{MA}^{*}-40\right.$, the numbers " 40 " are not 


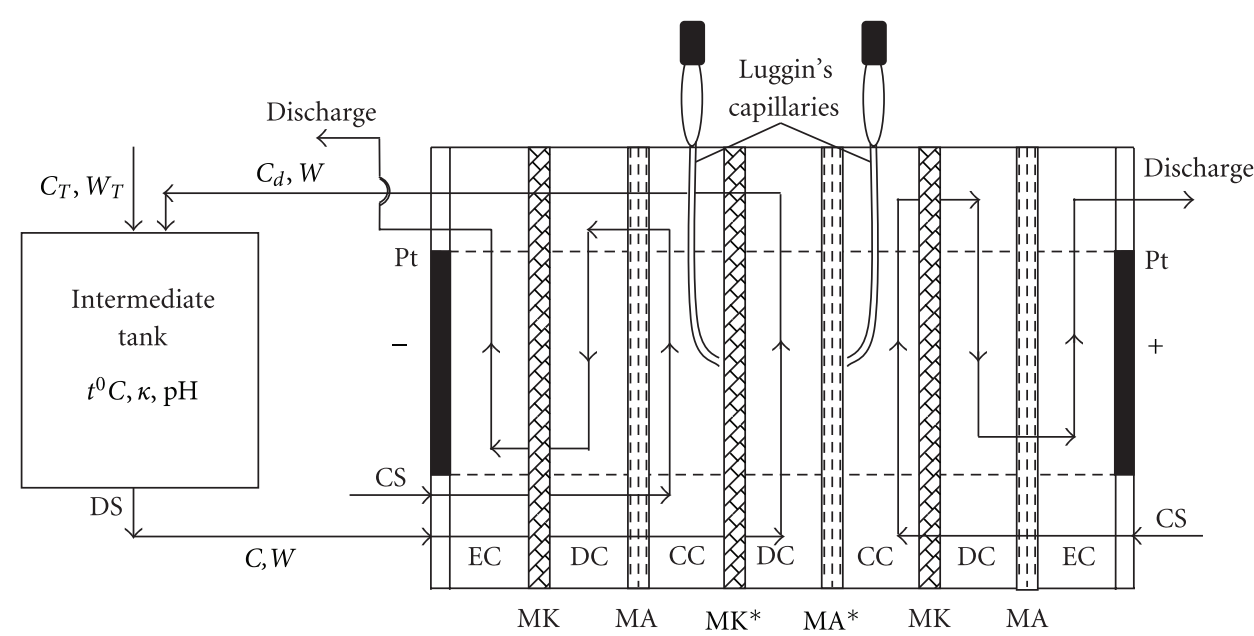

FIgURE 2: Principal scheme of the experimental setup used for measuring mass-transfer characteristics. A desalting (DS) and two concentrating (CS) streams, desalination (DC), concentration (CC) and electrode (EC) channels, and polarizing platinum electrodes (Pt) are shown. Dashed straight lines mark out the active section of membrane stack polarized by electric current.

shown). They can be commercial membranes or modified ones. Auxiliary commercial MK-40 and MA-40 membranes serve to separate the products of electrode reactions from the central compartment under study.

Two plastic Luggin's capillaries $(0.5 \mathrm{~mm}$ in external diameter) are built in the spacer. Both capillary tips are situated at the center of polarized area in CC at about $0.5 \mathrm{~mm}$ from the surface of the membrane forming the central DC. Another end of each capillary is connected to a reservoir with a $(0.02 \mathrm{M}) \mathrm{NaCl}$ solution where a measuring $\mathrm{Ag} / \mathrm{AgCl}$ electrode is inserted.

The membrane stack imitates an industrial electrodialyser with internal collectors. At the stack entrance, each compartment has a nonpolarized section of $5 \mathrm{~cm}$ length for hydrodynamic stabilization of the solution flow. The polarized membrane area is $3 \mathrm{~cm}$ in width $(a)$ and $10 \mathrm{~cm}$ in length $(L)$, the total membrane length is $22 \mathrm{~cm}$. Our previous investigations $[29,30]$ showed that the masstransfer characteristics obtained in a stack of $L=10 \mathrm{~cm}$ in length can be quantitatively scaled to predict the behavior of industrial electrodialysers.

An intermediate tank, inserted into the desalting stream (Figure 2), contains a stirrer and sensors to control temperature, $\mathrm{pH}$, and specific electrical conductivity $(\kappa)$. In the concentrating streams (CS), a $0.02 \mathrm{M} \mathrm{NaCl}$ solution is supplied from a separate tank (not shown in Figure 2), it continuously passes through auxiliary CC and DC, then through EC and is discharged. The average linear flow velocity in all compartments is equal to $2.5 \mathrm{~cm} \mathrm{~s}^{-1}$.

Before the experiment, the tank, the central desalination compartment, and the hoses were filled with $1200 \mathrm{~mL}$ of a $0.03 \mathrm{M} \mathrm{NaCl}$ solution. Then a constant voltage controlled with the Luggin's capillaries (Figure 2) was applied and electrodialysis process was realized at $25 \pm 0.5^{\circ} \mathrm{C}$ maintained in the tank. The solution circulated through the intermediate tank and the central DC with volume flow rate $W$. The salt concentration in the tank decreased with time because of the electrodialysis desalination: the outlet concentration, $C_{d}$, was lower than the inlet one, $C$. Besides, there were changes in $\mathrm{pH}$ of the solution passed through the DC due to different rates of water splitting at the cation-exchange (MK-40 or $\mathrm{MK}-40 / \mathrm{Nf}$ ) and the anion-exchange (MA-40 or MA-40M) membranes. In order to maintain $\mathrm{pH}=7$ in the solution in the tank, alkaline $(\mathrm{NaOH})$ or acid $(\mathrm{HCl})$ solution was added into the tank, depending on the sign of the $\mathrm{pH}$ changes in the outlet solution. The desalination process was realized in quasi-steady-state conditions, the amount of the solution put in the system so that allowed us to keep a slow (less than $1 \%$ per minute) [29] decrease in the electrolyte concentration of the solution in the intermediate tank. The total duration of every run was 8-10 hours. The electric current, as well as the specific conductivity of the solution (converted then into the $\mathrm{NaCl}$ concentration) in the tank were measured as functions of time.

The range of $\mathrm{NaCl}$ concentrations used in the experiments $(0.001 \mathrm{M} \leq C \leq 0.03 \mathrm{M})$ is chosen in a way to be sure that the co-ion transfer through the membranes is negligible, as well as that of carbonic acid dissociation products, which may appear in the desalinated solution due to dissolved atmospheric carbon dioxide. Experimental data by Sheldeshov et al. [31] and Gnusin et al. [32] as well as our calculations with help of the microheterogeneous model [33] show that the co-ion transfer through MK-40, MA-40, and similar heterogeneous membranes at current densities close to the limiting one becomes negligible if the difference between the salt concentration at the enriched and depleted membrane interfaces is less than $0.1 \mathrm{M}$. According to our estimations made earlier [29], noticeable carbon dioxide absorption from air and contribution of carbonic acid dissociation products to charge transfer through anion-exchange membranes occur at feed $\mathrm{NaCl}$ concentrations lower than $0.5 \times 10^{-3} \mathrm{M}$.

The mass-transfer rate may be found from the rate of the salt concentration decrease in the tank. In fact, the salt 
concentration in the tank varies due to ion transfer through IEMs in the DC and due to addition of alkaline (or acid) solution into the tank in order to maintain $\mathrm{pH}=7$. The description of material balance in the tank conducts to $[18,19]$ :

$$
k_{i}=\frac{i_{i}}{F C}=-\frac{V_{\mathrm{sol}}}{S C} \frac{d C}{d t}+\frac{c_{T} W_{T}}{S C}
$$

where $i_{i}$ is the partial current density of salt counterion (in our case it is ion $\mathrm{Na}^{+}$for cation-exchange membrane and ion $\mathrm{Cl}^{-}$for anion-exchange membrane) through the membrane under study; $C$ is the current salt $(\mathrm{NaCl})$ concentration in the tank; $k_{i}$ (defined as $i_{i} / F C$ ) is the mass-transfer coefficient characterizing the salt counterion transfer rate through the membrane under study; $V_{\text {sol }}$ is the volume of solution in the desalting stream (including its volume in the tank, in the DC, and in the hoses); $W_{T}$ and $c_{T}$ are the volume flow rate and the concentration of the solution $(\mathrm{NaOH}$ or $\mathrm{HCl}$ ) added into the tank to maintain $\mathrm{pH}=7$, respectively; $S$ is the membrane active surface. The first term in right-hand side of (1) shows the rate of concentration variation in the $\operatorname{tank}\left(V_{\text {sol }}(d C / d t)\right)$ divided by $S C$. The rate of concentration variation in the tank depends on the rate of ED desalination $\left(k_{i} S C\right)$ and the rate of alkaline or acid addition $\left(c_{T} W_{T}\right)$.

Equation (1) assumes that there is no salt co-ion flux through both membranes forming the desalination compartment. As it is noted above, the range of feed concentrations was chosen in a way to satisfy the negligible co-ion flux assumption.

Equation (1) is applied if the mass-transfer coefficient is calculated for the salt counterion passing through the membrane, which generates less $\mathrm{H}^{+}$and $\mathrm{OH}^{-}$ions than the other one forming the desalination compartment. For example, it is the case of $\mathrm{Na}^{+}$transfer through the MK-40 membrane making a pair with a MA-40 membrane. In this case, $\mathrm{NaOH}$ is added into the tank to compensate the excess of $\mathrm{H}^{+}$ions produced at the MA-40 membrane. To calculate the mass-transfer coefficient of $\mathrm{Cl}^{-}$ion for the MA-40 only the first term in the right-hand side of (1) should be taken into account, as no $\mathrm{Cl}^{-}$is added into the tank, and (1) becomes

$$
k_{i}=\frac{i_{i}}{F C}=-\frac{V_{\text {sol }}}{S C} \frac{d C}{d t} .
$$

We have a similar situation in the case of MK-40/Nf membrane making the DC with MA-40M membrane $(\Delta \varphi>4 \mathrm{~V})$. The rate of water splitting is essentially less than that in $\mathrm{MK}$ 40/MA-40 system; however, a small quantity of $\mathrm{NaOH}$ is needed to compensate the excess of $\mathrm{H}^{+}$ions produced at the MA-40M membrane.

The evaluated maximal measurement error in determination of $k_{i}$ was $6 \%$.

The effective transport number of an ion transported through the membrane is defined as the ratio of the partial current density of this ion to the total current density $i$ :

$$
T_{i}=\frac{i_{i}}{i}
$$

If the co-ion transport is not taken into account, the sum of salt cation $\left(\mathrm{Na}^{+}\right)$and proton $\left(\mathrm{H}^{+}\right)$transport numbers in a cation-exchange membrane, as well as the sum of salt anion $\left(\mathrm{Cl}^{-}\right)$and hydroxyl $\left(\mathrm{OH}^{-}\right)$transport numbers in an anionexchange membrane is equal to unity:

$$
T_{\mathrm{Na}^{+}}+T_{\mathrm{H}^{+}}=T_{\mathrm{Cl}^{-}}+T_{\mathrm{OH}^{-}}=1
$$

$T_{\mathrm{H}^{+}}$and $T_{\mathrm{OH}^{-}}$characterize the rate of water splitting in a membrane system. Their values are readily found after determination of $k_{i}$, according to (1)-(4).

\section{Concentration Dependence of Mass-Transfer Coefficient and Effective Transport Numbers}

The results of study of mass-transfer characteristics of desalination channels in a cell shown in Figure 2 and formed by MK-40//MA-40 and MK-40/Nf//MA-40M membrane pairs are shown in Figures 3 and 4 and Table 2. The data were obtained at a potential difference $\Delta \varphi$ (registered with Luggin's capillaries as shown in Figure 2) equal to 2.5, 4.0, or $6.0 \mathrm{~V}$ per cell pair. A potential difference was fixed while the feed concentration decreased with time since a fixed volume of solution circulated through a central desalination compartment and a tank, as it is described in Section 3. Total $\left(i_{\text {tot }}\right)$ and partial $\left(\mathrm{Na}^{+}\right.$and $\mathrm{H}^{+}$ions through cationexchange membranes and $\mathrm{Cl}^{-}$and $\mathrm{OH}^{-}$ions through anionexchange ones, resp.) current densities are shown in Figure 5 as functions of the feed $\mathrm{NaCl}$ concentration, in the case where the potential drop across a cell pair was $4 \mathrm{~V}$.

The data presented in Figure 3 show that when the value of potential drop per cell pair $\Delta \varphi$ is fixed, the masstransfer coefficients of salt counterions grow with decreasing feed $\mathrm{NaCl}$ concentration for all investigated membranes. For both cation- and anion-exchange membranes, this growth is more important in the case of surface-modified membranes (Figure 3, Table 2).

The dependence of mass-transfer coefficient on $\Delta \varphi$ in case of fixed $\mathrm{NaCl}$ concentration is more complicated. When $\Delta \varphi$ is growing, there is a tendency to equalization of the mass-transfer rates found in systems with both modified and commercial membranes. After passing $4 \mathrm{~V}$, a deceleration of mass-transfer rate growth or even its descend with rising $\Delta \varphi$ occurs, Figures 3(b) and 3(c).

As expected [34], the effective transport numbers of water splitting products $T_{\mathrm{H}^{+}\left(\mathrm{OH}^{-}\right)}$(Figure 4) grow with diluting solution at fixed $\Delta \varphi$ and with increasing $\Delta \varphi$ at fixed feed solution concentration, for all membranes. At $\Delta \varphi=$ $2.5 \mathrm{~V}$ and $\Delta \varphi=4.0 \mathrm{~V}$, the values of $T_{\mathrm{H}^{+}\left(\mathrm{OH}^{-}\right)}$are relatively low, especially for modified membranes $\left(T_{\mathrm{H}^{+}\left(\mathrm{OH}^{-}\right)}<0.15\right)$ (Figures 4(a) and 4(b)), while a high increase of $\mathrm{Na}^{+}$and $\mathrm{Cl}^{-}$mass-transfer coefficients is registered (Figures 3(a) and $3(\mathrm{~b}))$. Further growth of potential drop $(\Delta \varphi>4 \mathrm{~V})$ leads to a more significant raise of $T_{\mathrm{H}^{+}\left(\mathrm{OH}^{-}\right)}$(Figure $4(\mathrm{c})$ ). At $\Delta \varphi=6.0 \mathrm{~V}$ and $C_{\mathrm{NaCl}}=0.005 \mathrm{M}, T_{\mathrm{H}^{+}}$and $T_{\mathrm{OH}^{-}}$ in commercial MK-40 and MA-40 membranes reach 0.22 and 0.35 , respectively. Hence, in these conditions $\mathrm{H}^{+}$and especially $\mathrm{OH}^{-}$ions make a noticeable competition with 
TABle 2: Ratio of $\mathrm{Na}^{+}$to $\mathrm{Cl}^{-}$mass-transfer coefficients for ED cells with modified and commercial membranes at different feed solution concentrations and potential drops per cell.

\begin{tabular}{|c|c|c|c|c|c|c|}
\hline \multirow{2}{*}{$C_{\mathrm{NaCl}}, \mathrm{mol} \mathrm{dm}^{-3}$} & \multicolumn{3}{|c|}{$k_{\mathrm{Na}^{+}}^{\mathrm{MK}-40 / \mathrm{Nf}} / k_{\mathrm{Na}^{+}}^{\mathrm{MK}-40}$} & \multicolumn{3}{|c|}{$k_{\mathrm{Cl}^{-}}^{\mathrm{MA}-40 \mathrm{M}} / k_{\mathrm{Cl}^{-}}^{\mathrm{MA}-40}$} \\
\hline & $2.5 \mathrm{~V}$ & $4.0 \mathrm{~V}$ & $6.0 \mathrm{~V}$ & $2.5 \mathrm{~V}$ & $4.0 \mathrm{~V}$ & $6.0 \mathrm{~V}$ \\
\hline 0.02 & $1.0 \pm 0.1$ & $1.2 \pm 0.1$ & $1.0 \pm 0.1$ & $1.0 \pm 0.1$ & $1.2 \pm 0.1$ & $1.0 \pm 0.1$ \\
\hline 0.01 & $1.2 \pm 0.1$ & $1.4 \pm 0.1$ & $1.0 \pm 0.1$ & $1.3 \pm 0.1$ & $1.3 \pm 0.1$ & $1.0 \pm 0.1$ \\
\hline 0.005 & $2.0 \pm 0.1$ & $1.7 \pm 0.1$ & $1.2 \pm 0.1$ & $1.8 \pm 0.1$ & $1.7 \pm 0.1$ & $1.2 \pm 0.1$ \\
\hline
\end{tabular}

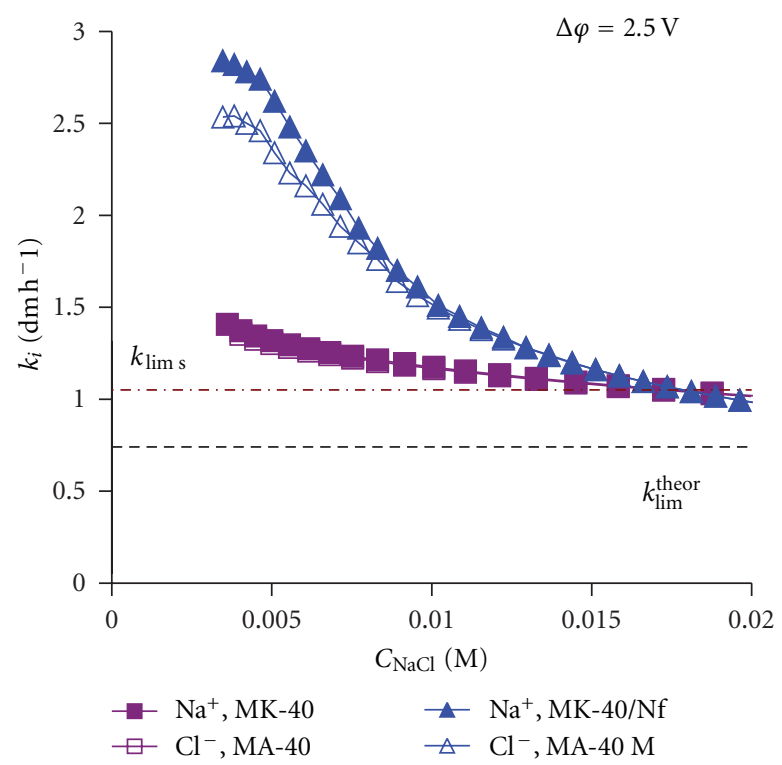

(a)

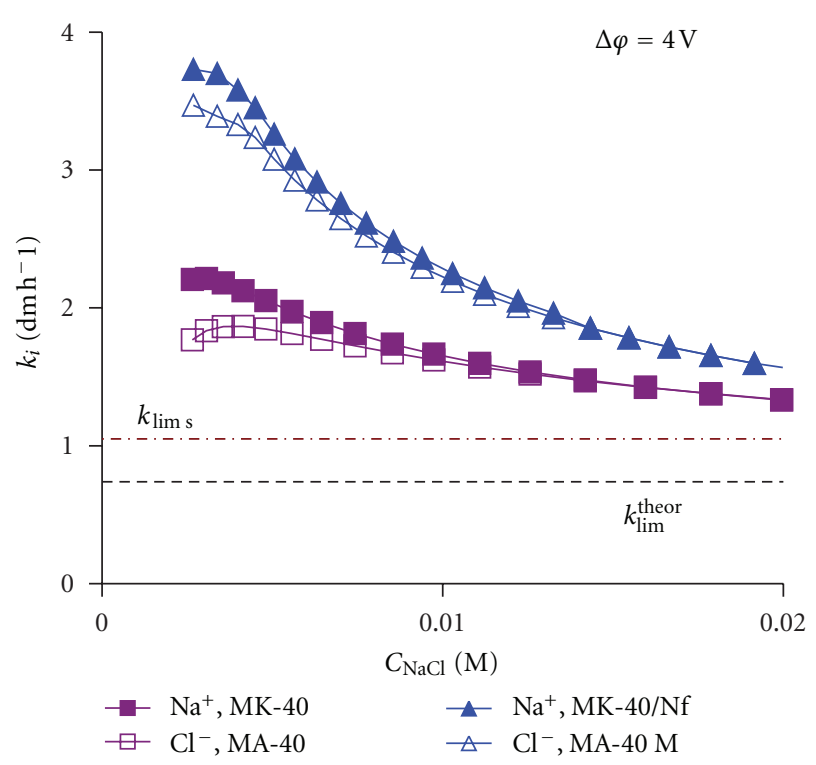

(b)

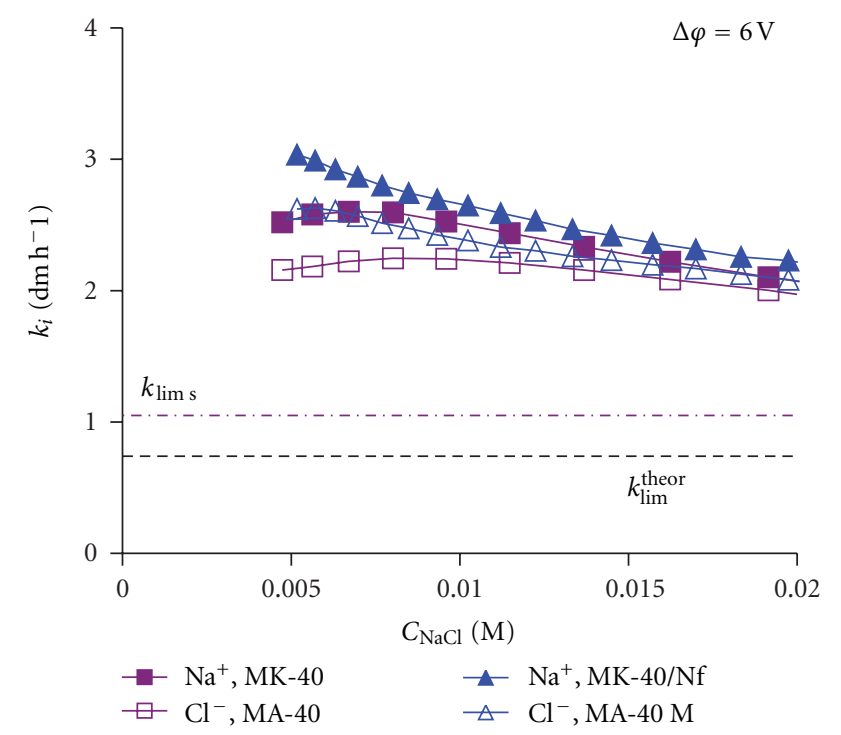

(c)

FIgURE 3: Concentration dependence of $\mathrm{Na}^{+}$mass-transfer coefficients across $\mathrm{MK}-40$ and $\mathrm{MK}-40 / \mathrm{Nf}$ cation-exchange membranes and $\mathrm{Cl}^{-}$ across MA-40 and MA-40M anion-exchange membranes forming desalination channels in a cell shown in Figure 2 under different potential drops $(\Delta \varphi)$ per cell pair: $2.5 \mathrm{~V}(\mathrm{a}), 4.0 \mathrm{~V}(\mathrm{~b})$, and $6 \mathrm{~V}(\mathrm{c})$. The limiting mass-transfer coefficient for the DC without spacer, $k_{\lim }^{\text {theor }}$, is calculated according to (7); the limiting mass-transfer coefficient for DC with spacer, $k_{\text {lim } s}$, is evaluated as described in the text. 


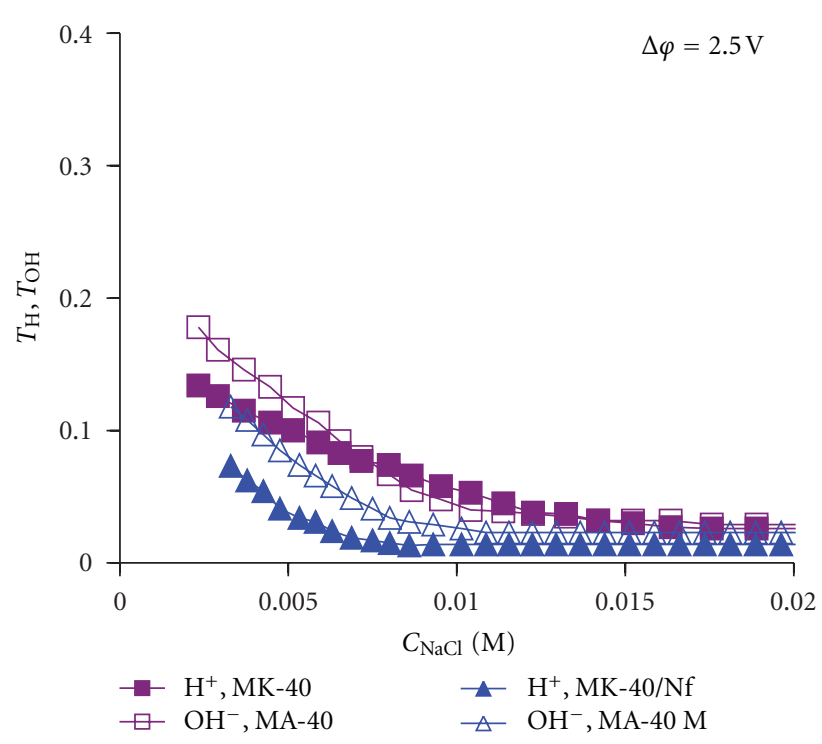

(a)

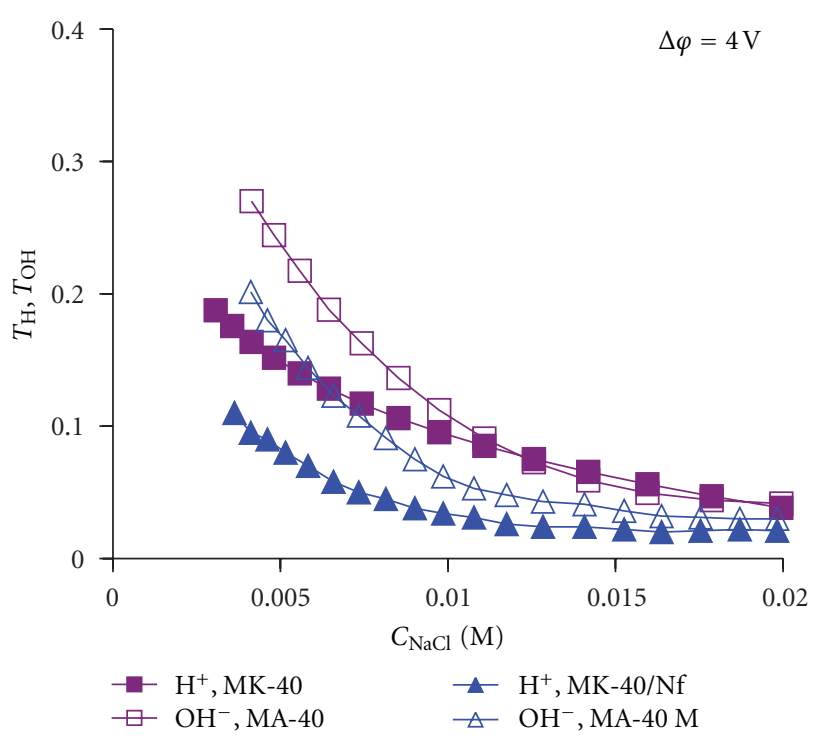

(b)

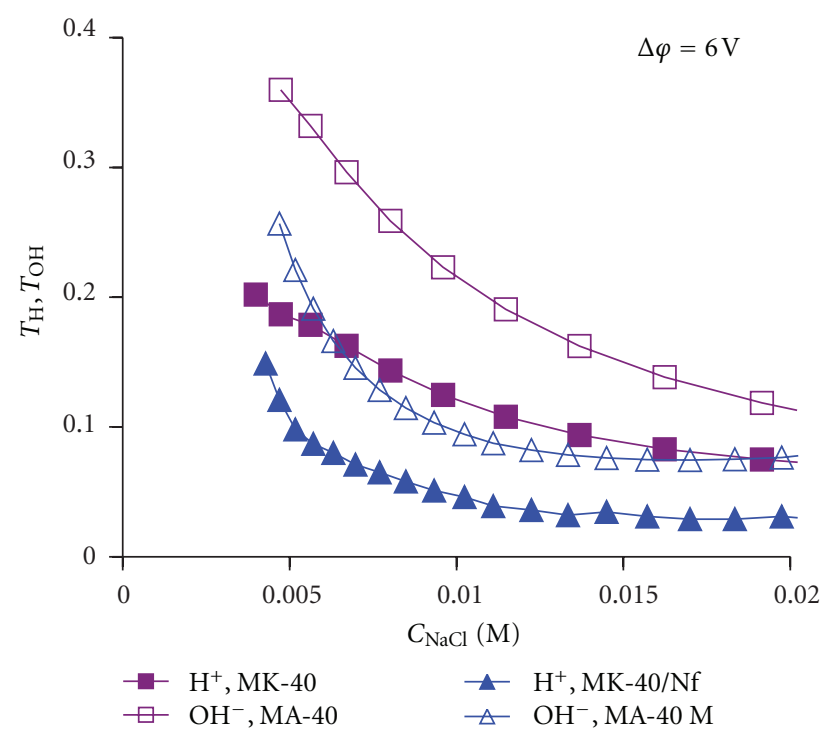

(c)

Figure 4: Concentration dependence of effective transport number of protons in cation-exchange membrane and that of hydroxyl ions in anion-exchange membranes forming MK-40//MA-40 and MK-40/Nf//MA-40M desalination channels at potential drops $(\Delta \varphi) 2.5 \mathrm{~V}(\mathrm{a})$, $4.0 \mathrm{~V}(\mathrm{~b})$, and $6.0 \mathrm{~V}(\mathrm{c})$ per cell pair.

$\mathrm{Na}^{+}$and $\mathrm{Cl}^{-}$ions in the electric charge transfer through the membranes.

As to the membranes with modified surface, MK40/Nf and MA-40M, both chemical treatment of a MA-40 membrane and casting a homogeneous ion conducting film onto a MK-40 membrane lead to a substantial decrease in water splitting product transport numbers. For example, at $C_{\mathrm{NaCl}}=0.005 \mathrm{M}$ and $\Delta \varphi=4.0$ (Figure $4(\mathrm{~b})$ ), $T_{\mathrm{OH}^{-}}$is equal to 0.23 and 0.15 , for MA-40 and MA- $40 \mathrm{M}$ membranes, respectively, while $T_{\mathrm{H}^{+}}$is equal to 0.14 and 0.06 for MK-40 and MK-40/Nf membranes, respectively.

The obtained results are in good agreement with the actual theoretical concepts of overlimiting mass-transfer mechanisms $[10,11,15,35,36]$ and with the experimental data found earlier with laboratory-scale ED cells $[10,18,19]$. First, these data confirm that electroconvection is the main mechanism of salt-ion transfer enhancement in intensive current modes. Following "classical" theoretical basics [3739], the mass-transfer coefficient has its limiting value, which corresponds to the limiting current density and does not depend on the concentration of feed solution. It follows from the combination of well-known Peers equation [38]:

$$
i_{\lim i}^{\text {theor }}=\frac{F D C}{\delta\left(T_{i}-t_{i}\right)}
$$

and the mass-transfer coefficient definition $k_{i}=i_{i} / F C(1)$, when assuming that no water splitting occurs and the 


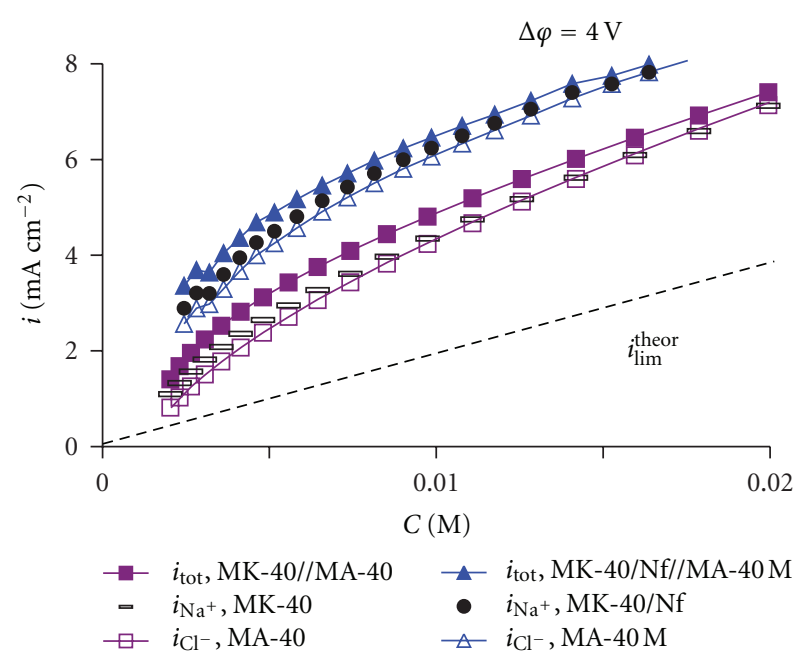

FIgure 5: Total $\left(i_{\text {tot }}\right)$ and partial current densities in the electrodialysis cell shown in Figure 2 as functions of the feed $\mathrm{NaCl}$ concentration. $i_{\mathrm{Na}^{+}}$and $i_{\mathrm{H}^{+}}$are the partial current densities of $\mathrm{Na}^{+}$and $\mathrm{H}^{+}$ions through cation-exchange membrane, respectively; $i_{\mathrm{Cl}^{-}}$and $i_{\mathrm{OH}^{-}}$are those of $\mathrm{Cl}^{-}$and $\mathrm{OH}^{-}$ions through anion-exchange membrane, respectively. The potential drop across the cell pair is $4 \mathrm{~V}$.

thickness of the Nernst diffusion boundary layer (DBL), $\delta$, is constant. Combining (1) and (5) leads to a simple equation:

$$
k_{\lim i}^{\text {theor }}=\frac{D}{\delta\left(T_{i}-t_{i}\right)} .
$$

Here $D$ is the electrolyte diffusion coefficient; $t_{i}$ is the transport number of the salt counterion in solution.

The limiting state in a desalination channel is determined by the membrane whose hosted counterions have lower mobility in solution [7]. It can be seen from (5): the difference $\left(T_{i}-t_{i}\right)$ is higher for lower $t_{i}$, as $T_{i}$ is very close to 1 ; hence, $i_{\lim i} i$ is lower. For this reason, when current density increases, the limiting state in the cell under study is first achieved at the cation-exchange membrane. According to "classical" theories, the salt concentration at this membrane becomes zero when the current density reaches $i_{\operatorname{lim~Na}}^{\text {theor }}$. In desalination channels without spacer, $i_{\operatorname{lim~Na}}^{\text {theor }}$ may be evaluated according to (7) [22], which is derived from the known Lévêque equation $[40,41]$ :

$$
i_{\lim \mathrm{Na}^{+}}^{\text {theor }}=\frac{1.43 C F D_{\mathrm{NaCl}}^{2 / 3} V^{1 / 3}}{L^{1 / 3} h^{1 / 3}\left(T_{\mathrm{Na}^{+}}-t_{\mathrm{Na}^{+}}\right)},
$$

where $V$ is the average flow rate, $L$ is the desalination length, and $h$ is the intermembrane distance. Equation (7) is valid for relatively short channels, $L<0.02 \mathrm{Vh}^{2} / D$.

Combining (5)-(7), it is relatively easy to find the limiting value of the mass-transfer coefficient for a desalination channel with the dimensions used in this study, but without spacer: $k_{\mathrm{lim}}^{\text {theor }}=0.74 \mathrm{dm} \mathrm{hr}^{-1}\left(D_{\mathrm{NaCl}}=1.61 \cdot 10^{-9} \mathrm{~m}^{2} \mathrm{c}^{-1}\right.$; $t_{\mathrm{Na}^{+}}=0.40$ [42]; $T_{\mathrm{Na}^{+}}=1$ ). This value is plotted in Figure 3 with dashed line. Usually introduction of a spacer into desalination channel results in a decrease of diffusion layer thickness due to enhancing convective transfer. Hence, $i_{\text {lim }}^{\text {theor }}$ and $k_{\text {lim }}^{\text {theor }}$ should increase according to (5) and (6). We can evaluate the increase in $k_{\text {lim }}^{\text {theor }}$ resulted from the introduction of spacer in DC as follows. In our former experiments [22, 34,43 ] it was shown that in the DC formed by MK-40 and MA-40 membranes, water splitting arises when the current density is close to the limiting current density at the cationexchange membrane $\left(i_{\text {lim Na}}{ }^{+}\right)$: the solution outgoing from the DC becomes slightly alkaline. With increasing current density up to (1.05-1.1) $i_{\operatorname{lim~Na}}{ }^{+}$, the rate of $\mathrm{H}^{+}$and $\mathrm{OH}^{-}$ ion generation at the anion-exchange membrane becomes higher than that at the cation-exchange membrane: the outgoing solution becomes acid. In actual experiments, a slight increase in $\mathrm{pH}$ of desalinated solution is registered for the DC, formed by MK-40 and MA-40 membranes, when the $\mathrm{NaCl}$ concentration is in the range $0.015-0.020 \mathrm{M}$ and $\Delta \varphi=$ $2.5 \mathrm{~V}$. In these conditions $T_{\mathrm{H}^{+}}$and $T_{\mathrm{OH}^{-}}$are close to zero. This fact allows us to assume that in these conditions the MK-40/S/MA-40 system is close to its limiting state; hence, $i \approx i_{\operatorname{lim~Na}}{ }^{+}$. The mass-transfer coefficient corresponding to this state is $k_{\operatorname{lims}}=\left(i_{\operatorname{lim~Na}}{ }^{+} / F C\right)$. The value of $k_{\operatorname{lims}}$ is plotted in Figure 3 with dash-dotted line. This value is about 35\% higher than that of $k_{\lim }^{\text {theor }}$ (valid for the same channel, but without spacer).

The increase in mass-transfer coefficients over $k_{\text {lims }}$ may be caused by the following effects coupled with the concentration polarization: exaltation effect connected with water splitting, gravitational convection, or electroconvection [10]. Our estimations show that at $\Delta \varphi \leq 4.0 \mathrm{~V}$ and at the values of the partial current densities of $\mathrm{H}^{+}\left(\mathrm{OH}^{-}\right)$ reached in our experiments (Figure 4), exaltation effect [10] cannot provide an increase in ion transfer more than 3-5\%. However, $k_{\mathrm{Na}^{+}}$and $k_{\mathrm{Cl}^{-}}$can exceed $k_{\text {lims s }}$ in several times. For example, at $C_{\mathrm{NaCl}}=0.005 \mathrm{M}$ and $\Delta \varphi \leq 4.0 \mathrm{~V}$ (Figure $4(\mathrm{~b})$ ) $k_{\mathrm{Na}^{+}} / k_{\mathrm{Cl}^{-}}$is equal to 2.5 and 3.3 for $\mathrm{MK}-40$ and $\mathrm{MK}-40 / \mathrm{Nf}$ membranes, respectively, and $k_{\mathrm{Cl}^{-}} / k_{\text {lims }}$ is equal to 1.8 and 3.1 for MA-40 and MA-40M, respectively. Gravitational convection weakens with diluting solution and is practically negligible in conditions of this experiment [10]. In contrast, electroconvection is enhanced with diluting solution $[10,11$, 22]. Apparently, it is the only mechanism able to enhance salt-ion transfer in conditions of our experiment.

The reasons for more prominent electroconvection in the DC with modified membranes are as follows. The application of sulfonated polytetrafluoroethylene (Nf) film on MK-40 surface results in a significant increase of water contact angle (Table 1). Water slips easier at more hydrophobic surface [20], facilitating the onset of electroconvection [10, 18, 19]. Another reason may be in lower water splitting in the cell with modified membranes. As it was shown by Choi et al. [44], mass-transfer rate through ion-exchange membranes rises with increasing Stokesian radius of counterion. This is apparently caused by the fact that a more hydrated counterion can involve a bigger volume in motion during electroconvection. $\mathrm{H}^{+}$and $\mathrm{OH}^{-}$ions carry the charge by "tunneling" from one water molecule to another without bringing liquid volume into motion (the Grotthus transport mechanism) hence, Stokesian radius of these ions is very small. As a result, an increase in the contribution of water 
splitting products to the charge transfer through the membrane weakens electroconvection. Moreover, the $\mathrm{H}^{+}$and $\mathrm{OH}^{-}$ions generated at the membrane/solution interface are carried away into the extended SCR and reduce the space charge density at a fixed current density [34], as a result, the electric body force generating electroconvection is also reduced.

The negative impact of $\mathrm{H}^{+}$and $\mathrm{OH}^{-}$ions generation on mass-transfer rate is especially noticeable in the case of commercial MA-40 membrane: the mass-transfer coefficient of both $\mathrm{Na}^{+}$and $\mathrm{Cl}^{-}$ions decreases at low feed concentrations when the voltage increases from $4.0 \mathrm{~V}$ to $6.0 \mathrm{~V}$ (Figures $3(b)$ and 3(c)). This result is typical for majority of anionexchange membranes, which generate more intensively $\mathrm{H}^{+}$ and $\mathrm{OH}^{-}$ions in comparison with the neighboring cationexchange membranes in a desalination channel [45].

It follows from experiments carried out with small laboratory-scale cells that a noticeable decrease in masstransfer rate (apparently due to suppression of electroconvection) takes place when $T_{\mathrm{H}^{+}\left(\mathrm{OH}^{-}\right)}$reaches a value in the range from 0.2 to 0.3 [34]. The decrease of $k_{\mathrm{Na}^{+}}$and $k_{\mathrm{Cl}^{-}}$in the DC imitating large-scale electrodialysers starts at somewhat smaller $T_{\mathrm{H}^{+}\left(\mathrm{OH}^{-}\right)}$values $(0.1-0.15)$ (Figures 3(b), 3(c), $4(\mathrm{~b})$, and $4(\mathrm{c}))$. Perhaps, this is caused by the fact that we register integral (averaged over the DC length) transport numbers. $T_{\mathrm{H}^{+}\left(\mathrm{OH}^{-}\right)}$can easily reach values of $0.2-0.3$ near the exit of DC, where the solution concentration decreases by 20-30\% compared to the inlet.

As noted above, the difference in the behavior of commercial and modified membranes decreases with increasing potential difference: the rates of mass transfer and water splitting are getting close (Figures 3 and 4 ). It is possible that the reason for that is in the convergence of water splitting rates for different membranes under high $\Delta \varphi$. Apparently the impact of the field effect [46] into water splitting rate increases with increasing $\Delta \varphi$, and in the range of high $\Delta \varphi$ the difference in catalytic activity of different fixed group is no longer the dominating factor. Thus, the benefit of the replacement of the secondary and tertiary amino groups with the quaternary ammonium bases (MA-40M) is not so noticeable at high $\Delta \varphi$ (Figure 3(c)).

In long desalination channels, $\mathrm{H}^{+}\left(\mathrm{OH}^{-}\right)$ions, produced at one of the membranes forming the channel, can reach the other membrane and then participate in competitive transfer through this membrane. Even if a part of the ions generated at the first membrane will be neutralized by the products of water splitting at the second one, the remained ions will reduce the current efficiency and contribute to suppression of electroconvection. Generally, as mentioned above, it is anion-exchange membrane which splits water more intensively. In addition of negative effects noted above, an excess of $\mathrm{H}^{+}$ions in the desalination compartment decreases the degree of dissociation of weak acids presented in natural waters, such as silicic acid, and hence, reduces their removal. An increase of $\mathrm{pH}$ in the concentrate compartment leads to formation of salt deposits. For these reasons, a decrease in water splitting rate at anion-exchange membrane is a key point in improvement of overlimiting electrodialysis.
Synergetic effect is achieved when both membranes are improved: the cation-exchange one in order to enhance electroconvection and the anion-exchange one in order to suppress water splitting.

\section{Conclusions}

Overlimiting electrodialysis can be essentially improved by applying specially modified ion-exchange membranes. The cation-exchange membrane was modified by a thin homogeneous ion-conducting but relatively hydrophobic (Nafion-type) layer in order to stimulate electroconvection and to reduce water splitting. The modification of the anionexchange membrane was aimed only at lowering water splitting rate at its surface. The behavior of modified and original commercial membranes (MA-40 and MK-40) was compared in a desalination channel imitating that in largescale electrodialysers. It is shown that, as well as in smallscale laboratory cells studied earlier, the $\mathrm{H}^{+}$and $\mathrm{OH}^{-}$ effective transport numbers in the membranes are reduced by about 2 times and hence, current efficiency increased correspondingly, when the commercial membranes were replaced with the modified ones. The salt-ion transfer intensified by electroconvection increases up to 3.5 times. The effect is maximum in rather diluted $(0.005 \mathrm{M} \mathrm{NaCl})$ solution at $4 \mathrm{~V}$ per cell pair. With increasing voltage, the mass-transfer coefficient continues to grow in the range 0.01 to $0.025 \mathrm{M}$ concentrations. However, it decreases at feed concentrations $<0.005 \mathrm{M} \mathrm{NaCl}$ and a fixed voltage. Apparently, the reason is in high water splitting rate, which occurs in very dilute solutions in spite of the modification of both membranes. Another reason is in participation in current transfer of hydrogen carbonate anions issued from dissolving of atmospheric $\mathrm{CO}_{2}$ in water, but this effect takes place at feed concentrations $<0.0005 \mathrm{M} \mathrm{NaCl}$.

Note that the ways and materials of modification are commercially available. In practical terms, this means that there are new opportunities to produce inexpensive ionexchange membranes effective in electrodialysis of dilute solutions.

\section{Acknowledgments}

Part of the work was realized within a French-Russian laboratory "Ion-exchange membranes and related processes". The authors are grateful to CNRS, France and to RFBR (Grants no. 11-08-93107-NCNIL, 11-08-96511, and 11-0893107), Russia, as well as FP7 "CoTraPhen" project PIRSESGA-2010-269135 for financial support of this work.

\section{References}

[1] Y. Zhang, K. Ghyselbrecht, B. Meesschaert, L. Pinoy, and B. Van der Bruggen, "Electrodialysis on RO concentrate to improve water recovery in wastewater reclamation," Journal of Membrane Science, vol. 378, no. 1-2, pp. 101-110, 2011.

[2] Y. Oren, E. Korngold, N. Daltrophe et al., "Pilot studies on high recovery BWRO-EDR for near zero liquid discharge approach," Desalination, vol. 261, no. 3, pp. 321-330, 2010. 
[3] J. Wood, J. Gifford, J. Arba, and M. Shaw, "Production of ultrapure water by continuous electrodeionization," Desalination, vol. 250, no. 3, pp. 973-976, 2010.

[4] V. I. Zabolotsky, V. V. Nikonenko, N. D. Pismenskaya, and A. G. Istoshin, "Electrodialysis technology for deep demineralization of surface and ground water," Desalination, vol. 108, no. 1-3, pp. 179-181, 1997.

[5] Y. Tanaka, R. Ehara, S. Itoi, and T. Goto, "Ion-exchange membrane electrodialytic salt production using brine discharged from a reverse osmosis seawater desalination plant," Journal of Membrane Science, vol. 222, no. 1-2, pp. 71-86, 2003.

[6] H. Strathmann, "Electrodialysis, a mature technology with a multitude of new applications," Desalination, vol. 264, no. 3, pp. 268-288, 2010.

[7] Y. Tanaka, Ion Exchange Membranes: Fundamentals and Applications, vol. 12 of Membrane Science and Technology, Elsevier, Amsterdam, The Netherlands, 2007.

[8] K. S. Spiegler, "Polarization at ion exchange membrane-solution interfaces," Desalination, vol. 9, no. 4, pp. 367-385, 1971.

[9] P. Długołecki, B. Anet, S. J. Metz, K. Nijmeijer, and M. Wessling, "Transport limitations in ion exchange membranes at low salt concentrations," Journal of Membrane Science, vol. 346, no. 1, pp. 163-171, 2010.

[10] V. V. Nikonenko, N. D. Pismenskaya, E. I. Belova et al., "Intensive current transfer in membrane systems: modelling, mechanisms and application in electrodialysis," Advances in Colloid and Interface Science, vol. 160, no. 1-2, pp. 101-123, 2010.

[11] I. Rubinstein and B. Zaltzman, "Electro-osmotically induced convection at a permselective membrane," Physical Review E, vol. 62, no. 2, pp. 2238-2251, 2000.

[12] J. Balster, M. H. Yildirim, D. F. Stamatialis et al., "Morphology and microtopology of cation-exchange polymers and the origin of the overlimiting current," Journal of Physical Chemistry $B$, vol. 111, no. 9, pp. 2152-2165, 2007.

[13] S. S. Dukhin, "Electrokinetic phenomena of the second kind and their applications," Advances in Colloid and Interface Science, vol. 35, no. C, pp. 173-196, 1991.

[14] N. A. Mishchuk and P. V. Takhistov, "Electroosmosis of the second kind," Colloids and Surfaces A, vol. 95, no. 2-3, pp. 119131, 1995.

[15] N. A. Mishchuk, "Concentration polarization of interface and non-linear electrokinetic phenomena," Advances in Colloid and Interface Science, vol. 160, no. 1-2, pp. 16-39, 2010.

[16] S. S. Dukhin and N. A. Mishchuk, "Intensification of electrodialysis based on electroosmosis of the second kind," Journal of Membrane Science, vol. 79, no. 2-3, pp. 199-210, 1993.

[17] S. J. Kim, S. H. Ko, K. H. Kang, and J. Han, "Direct seawater desalination by ion concentration polarization," Nature Nanotechnology, vol. 5, no. 4, pp. 297-301, 2010.

[18] E. D. Belashova, N. A. Melnik, N. D. Pismenskaya et al., "Overlimiting mass transfer through cation-exchange membranes modified by NAFION film and carbon nanotubes," Electrochimica Acta, vol. 59, pp. 412-423, 2012.

[19] N. D. Pismenskaya, V. V. Nikonenko, N. A. Melnik et al., "Evolution with time of hydrophobicity and microrelief of a cationexchange membrane surface and its impact on overlimiting mass transfer," The Journal of Physical Chemistry B, vol. 116, no. 7, pp. 2145-2161, 2012.

[20] M. Z. Bazant and O. I. Vinogradova, "Tensorial hydrodynamic slip," Journal of Fluid Mechanics, vol. 613, pp. 125-134, 2008.

[21] N. D. Pismenskaya, E. I. Belova, V. V. Nikonenko et al., "Lower rate of $\mathrm{H}^{+}\left(\mathrm{OH}^{-}\right)$ions generation at an anion-exchange membrane in electrodialysis," Desalination and Water Treatment, vol. 21, no. 1-3, pp. 109-114, 2010.

[22] E. I. Belova, G. Y. Lopatkova, N. D. Pismenskaya, V. V. Nikonenko, C. Larchet, and G. Pourcelly, "Effect of anion-exchange membrane surface properties on mechanisms of overlimiting mass transfer," Journal of Physical Chemistry B, vol. 110, no. 27, pp. 13458-13469, 2006.

[23] G. Z. Nefedova, Z. V. Klimov, G. S. Sapozhnikov, and Katalog, "Ionitovye membrany" (Russian), M: NIITEKhIM, 1977.

[24] R. Simons, "Electric field effects on proton transfer between ionizable groups and water in ion exchange membranes," Electrochimica Acta, vol. 29, no. 2, pp. 151-158, 1984.

[25] V. I. Zabolotsky, N. V. Sheldeshov, and N. P. Gnusin, "Dissociation of water molecules in systems with ion-exchange membranes," Russian Chemical Reviews, vol. 57, pp. 801-808, 1988.

[26] N. D. Pismenskaya, Y. A. Fedotov, V. V. Nikonenko et al., Patent 2008141949 Russian Federation, B 01D71/60 (2006.01), B01D7/06 (2006.01). Method of ion exchange membrane preparation, Filing date 22.10.2008, Issue date 27.04.2010.

[27] N. P. Berezina, S. V. Timofeev, and N. A. Kononenko, "Effect of conditioning techniques of perfluorinated sulphocationic membranes on their hydrophylic and electrotransport properties," Journal of Membrane Science, vol. 209, no. 2, pp. 509-518, 2002.

[28] N. P. Berezina, N. A. Kononenko, O. A. Dyomina, and N. P. Gnusin, "Characterization of ion-exchange membrane materials: properties vs structure," Advances in Colloid and Interface Science, vol. 139, no. 1-2, pp. 3-28, 2008.

[29] E. V. Laktionov, N. D. Pismenskaya, V. V. Nikonenko, and V. I. Zabolotsky, "Method of electrodialysis stack testing with the feed solution concentration regulation," Desalination, vol. 151, no. 2, pp. 101-116, 2003.

[30] V. V. Nikonenko, N. D. Pismenskaya, A. G. Istoshin, V. I. Zabolotsky, and A. A. Shudrenko, "Description of mass transfer characteristics of ED and EDI apparatuses by using the similarity theory and compartmentation method," Chemical Engineering and Processing: Process Intensification, vol. 47, no. 7, pp. 1118-1127, 2008.

[31] N. V. Sheldeshov, V. V. Ganych, and V. I. Zabolotskii, “Transport number of salt ions and water dissociation products in cation and anion-exchange membranes," Soviet Electrochemistry, vol. 23, pp. 11-15, 1991.

[32] N. P. Gnusin, N. P. Berezina, N. A. Kononenko, and O. A. Dyomina, "Transport structural parameters to characterize ion exchange membranes," Journal of Membrane Science, vol. 243, no. 1-2, pp. 301-310, 2004.

[33] V. I. Zabolotsky and V. V. Nikonenko, "Effect of structural membrane inhomogeneity on transport properties," Journal of Membrane Science, vol. 79, no. 2-3, pp. 181-198, 1993.

[34] V. V. Nikonenko, N. D. Pis'menskaya, and E. I. Volodina, "Rate of generation of ions $\mathrm{H}^{+}$and $\mathrm{OH}^{-}$at the ion-exchange membrane/dilute solution interface as a function of the current density," Russian Journal of Electrochemistry, vol. 41, no. 11, pp. 1205-1210, 2005.

[35] I. Rubinstein and B. Zaltzman, "Extended space charge in concentration polarization," Advances in Colloid and Interface Science, vol. 159, no. 2, pp. 117-129, 2010.

[36] M. A.-K. Urtenov, E. V. Kirillova, N. M. Seidova, and V. V. Nikonenko, "Decoupling of the Nernst-Planck and Poisson equations. Application to a membrane system at overlimiting currents," Journal of Physical Chemistry B, vol. 111, no. 51, pp. 14208-14222, 2007. 
[37] K. S. Spiegler, "Transport processes in ionic membranes," Transactions of the Faraday Society, vol. 54, pp. 1408-1428, 1958.

[38] A. M. Peers, "Membrane phenomena," Discussions of the Faraday Society, vol. 21, pp. 124-125, 1956.

[39] F. G. Helfferich, Ion Exchange, McGraw-Hill, New York, NY, USA, 1962.

[40] J. S. Newman, Electrochemical Systems, Prentice Englewood Cliffs, New York, NY ,USA, 1973.

[41] M. A. Lévêque, Les Lois de la Transmission de Chaleur par Convection, vol. 12-13 of Annales des Mines, Memoires, 1928.

[42] R. A. Robinson and R. H. Stokes, Electrolyte Solutions, Butterworths, London, UK, 1968.

[43] V. I. Zabolotsky, V. V. Nikonenko, N. D. Pismenskaya et al., "Coupled transport phenomena in overlimiting current electrodialysis," Separation and Purification Technology, vol. 14, no. 1-3, pp. 255-267, 1998.

[44] J. H. Choi, H. J. Lee, and S. H. Moon, "Effects of electrolytes on the transport phenomena in a cation-exchange membrane," Journal of Colloid and Interface Science, vol. 238, no. 1, pp. 188195, 2001.

[45] Y. Tanaka, "Water dissociation reaction generated in an ion exchange membrane," Journal of Membrane Science, vol. 350, no. 1-2, pp. 347-360, 2010.

[46] S. Mafé, P. Ramírez, and A. Alcaraz, "Electric field-assisted proton transfer and water dissociation at the junction of a fixed-charge bipolar membrane," Chemical Physics Letters, vol. 294, no. 4-5, pp. 406-412, 1998. 

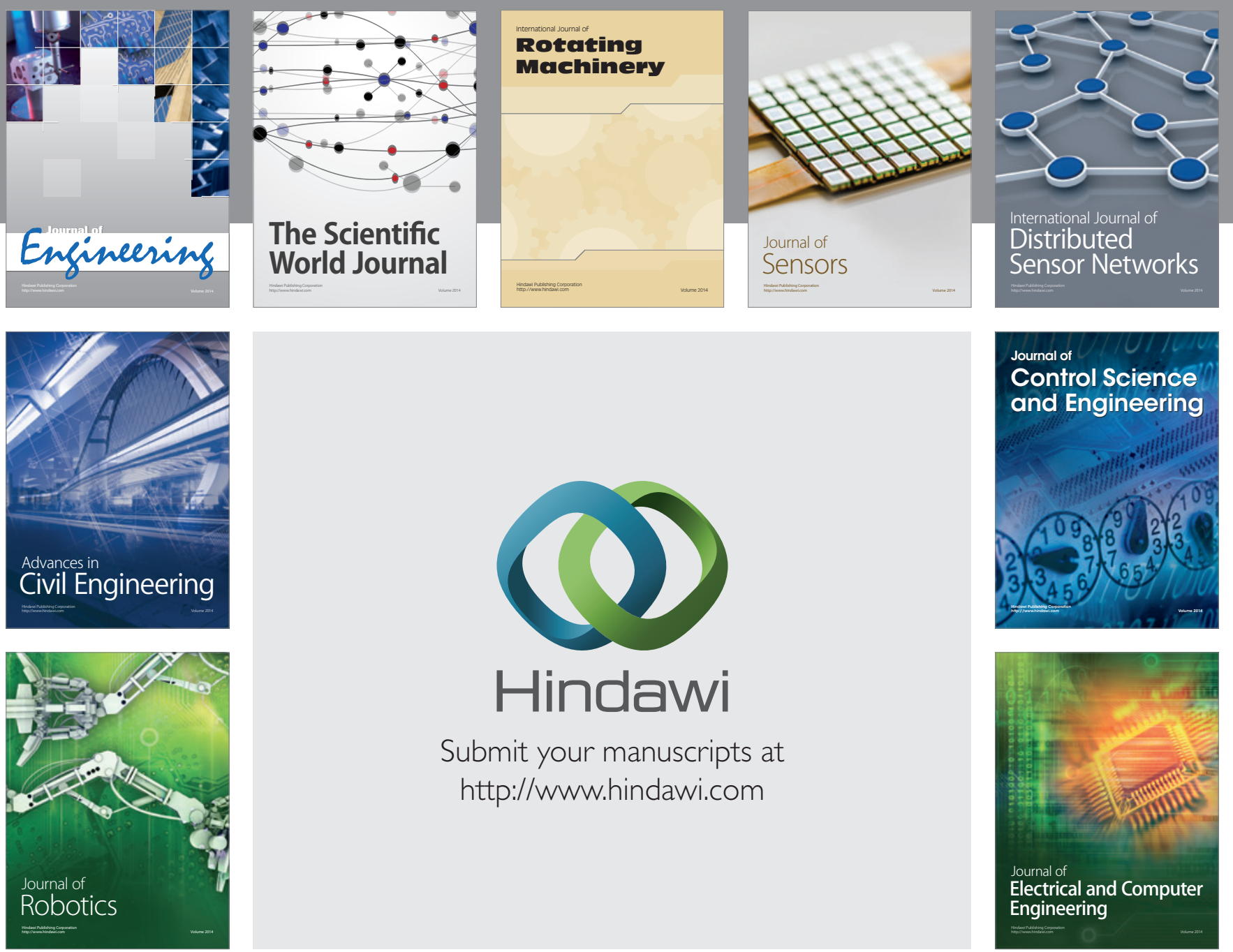

Submit your manuscripts at

http://www.hindawi.com
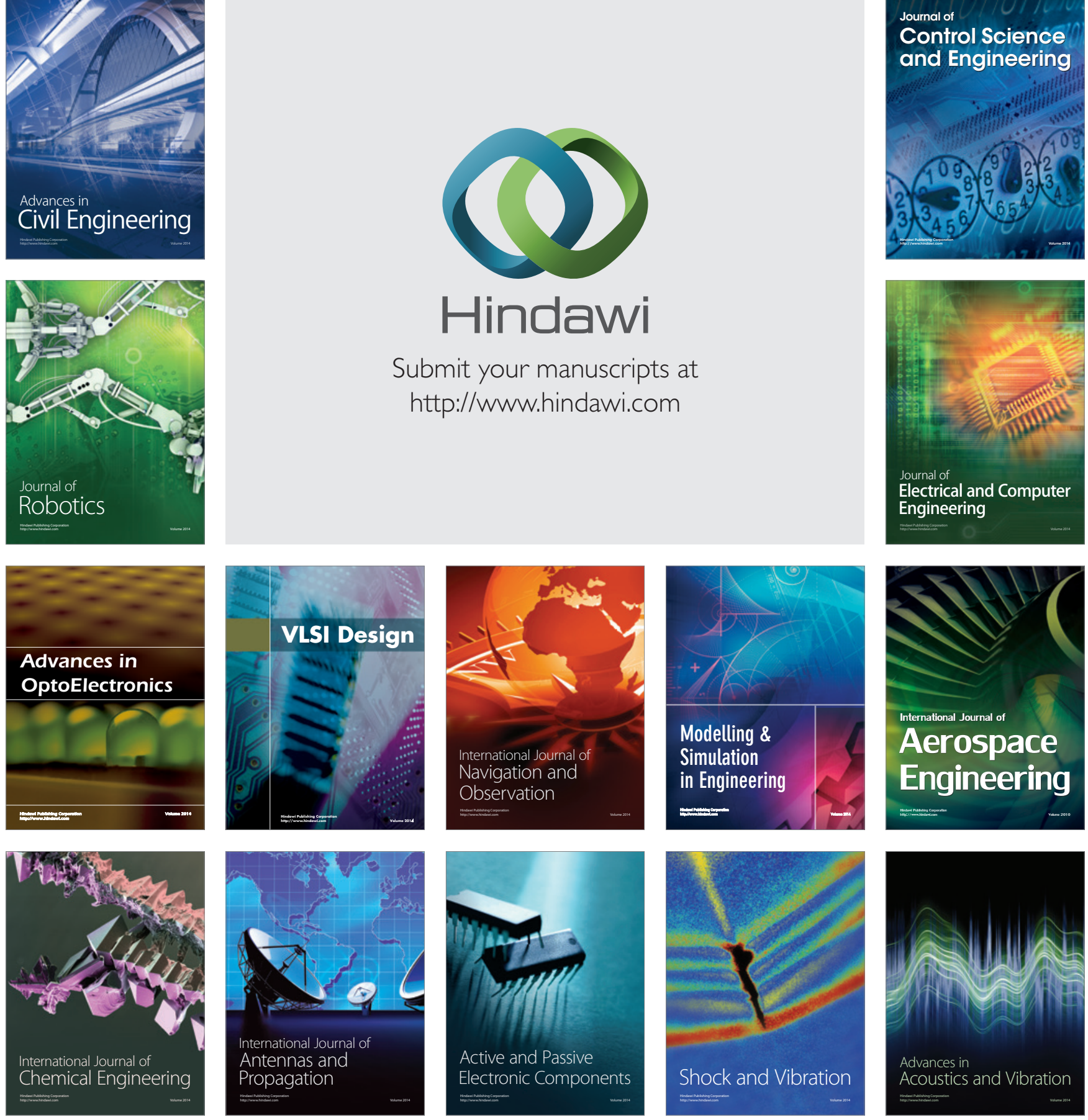